\title{
Treatment Landscape of Ductal Carcinoma In Situ
}

\author{
Anca Chelariu-Raicu*, Nadia Harbeck \\ Department of Obstetrics and Gynecology, Breast Center and CCC Munich, Germany \\ Ludwig Maximilian University, University Hospital, Munich, Germany
}

*Corresponding author:

Anca Chelariu-Raicu, MD

Department of Obstetrics and Gynecology,

Breast Center and CCC Munich, Germany

E-Mail: Anca.Chelariu-Raicu@med.uni-muenchen.de

\begin{abstract}
Rezumat
Îmbunătățiri majore ale investigaților imagistice mamare din ultimii 40 de ani au rezultat la o incidență crescută a diagnosticului carcinomului ductal in situ (CDIS). Odată cu schimbarea metodei de diagnostic clinic, mai exact de la metoda de palpare a unei mase tumorale de dimensiuni mari, la detecția prin mamografie a unor leziuni de dimensiuni mult mai mici până la $10 \mathrm{~mm}$, conceputul de chirurgie mamară conservatoare s-a dezvoltat ca metodă principală de tratament. Excizia chirurgicală şi tehnicile oncoplastice au îmbunătățit atât acuratețea procedurii, cât şi rezultatul cosmetic ulterior. Datorită posibilității de diagnostic a leziunilor mici, tratamentul carcinomului ductal (CDIS) este limitat în aproximativ 40\% din cazuri doar la intervenția chirurgicală, fie prin excizie locală, fie prin mastectomie. Pentru un grup selectat de paciente care prezintă factor de risc, intervenția chirurgicală conservatoare va fi completată de radioterapie şi hormonoterapie. Acest articol descrie atât rolul chirurgiei conservatoare în tratamentul CDIS cât şi interpretarea datelor clinice recente pe tema terapiei adjuvante. De asemenea, având în vedere dezvoltărea recentă a testelor genetice, biologia moleculara a CDIS este abordată într-o secțiune separată a articolulul.
\end{abstract}

Cuvinte cheie: carcinom ductal in situ, chirurgie mamară conservatoare, radiații, terapie țintită, biologie tumorală

\section{Abstract}

Major improvements in breast imaging over the last 40 years have led to increased numbers of patients diagnosed with ductal carcinoma in situ (DCIS). Subsequently, after shifting the diagno- 
sis from palpable breast masses to detection of small about $10 \mathrm{~mm}$ lesions by mammography, the concept of breast conservative surgery was developed. Therefore, surgical excision and oncoplastic techniques have improved both accuracy of the procedure and subsequent cosmetic result. Approximately $40 \%$ of DCIS cases are treated by surgery alone, i.e., local excision, or mastectomy. In addition, radiotherapy and endocrine therapy are recommended for patients after breast conservation. Recently, results from clinical trials investigating the benefit of targeted therapies were reported, however without any meaningful impact on patient outcome. In this review, we summarize our current understanding of the role of conservative surgery in DCIS treatment and present relevant clinical trials in which conservative surgery, radiation, and adjuvant therapies were investigated. We also outline the tumor biology of DCIS in light of recent developments of genetic assays and their potential utility in the clinic.

Key words: DCIS, conservative breast surgery, radiation, targeted therapy, tumor biology

\section{Introduction}

Ductal carcinoma in situ (DCIS) is defined as preinvasive breast cancer confined to the milk ducts, often diagnosed in asymptomatic women (1). Moreover, DCIS accounts for approximately $15-25 \%$ of mammogramdetected breast cancers (2). This early detection is especially important considering that these preinvasive lesions vary widely from low to high grade, the latter of which may progress to invasive cancer, or even harbor foci of invasive breast cancer. DCIS is somewhat paradoxical in nature; there is essentially no risk of metastatic disease or death, but very high risk of local recurrence.

Standard of care for DCIS management includes surgery, radiation, and endocrine therapy (3). Because most DCIS lesions detected via routine mammography are small, surgical treatment is usually performed as lumpectomy. International guidelines recommend addition of radiation after lumpectomy (4); however, some DCIS lesions may be low risk, or unlikely to progress after removal. Currently, there are few available biomarkers to determine which patients are at high risk for local recurrence and should thus receive radiation treatment (5). As such, it is believed that many patients with DCIS are overtreated. The lack of biomarkers is partially due to the difficulty of performing molecular testing on precancerous lesions, which are often damaged or too small for further examination (6).

Interestingly, neither radiation nor endocrine therapy have any impact on the 10year rates of DCIS mortality (4). This finding supports the above-mentioned observation that adjuvant therapy may be overtreatment in certain cases (7) and is in line with two other recent studies $(8,9)$. Moreover, a retrospective study by the Surveillance, Epidemiology, and End Results (SEER) Program proposed that, in patients with low-grade DCIS, the overall survival remains the same whether or not patients underwent surgery (9). However, due to the uncertainty regarding the individual risk of DCIS progression to invasive cancer and the general anxiety in women with this diagnosis, management and treatment of DCIS still generally consists of surgery and radiation in case of breast conservation.

This review details the criteria for conservative DCIS management (Table 1). We then briefly summarize the current indications of radiation and discuss concepts for endocrine and targeted therapy based on recent randomized phase III clinical trials. Finally, we present potential directions for a molecular classification of DCIS to differentiate harmless DCIS lesions from potentially hazardous ones. 
Table 1. Statements (Adapted from German Guidelines) (11)

Treatment Statements for DCIS

Adjuvant treatment has no impact on overall survival and should be discussed with the patient individually

Radiotherapy reduces the risk of ipsilateral (invasive or non- invasive) recurrence by $50 \%$

Endocrine therapy may have a small effect on ipsilateral invasive and DCIS recurrences

\section{Standard of Care}

The surgery-based treatment options for DCIS are quite broad. They include wide excision alone, wide excision with subsequent radiation and/or endocrine therapy, or unilateral/ bilateral mastectomy (10). Overall, it is important to assess a patient's individual values such as cosmesis, availability for regular medical follow-up care and level of anxiety regarding local relapse, to determine what treatment option is best. Breast conserving surgery (BCS), including complete excision of the tumor with $>2 \mathrm{~mm}$ margins $\mathrm{t}$, is the gold standard for DCIS therapy and is currently the therapy of choice for most women (11). Individualizing treatment for patients with DCIS has become more important in recent years (3).

In contrast to invasive breast cancer, sentinel lymph node biopsy is not routinely performed since DCIS lesions rarely include invasive cancer cells (12). However, the presence of a large DCIS lesion or several separate DCIS lesions increases the risk of progression into invasive cancer and thus the probability of invasive foci within the DCIS lesion. In this case, a mastectomy together with sentinel lymph node biopsy may be indicated $(13,14)$. As discussed in more detail below, tumor resection with adequate cancerfree margins is essential for a successful excision of DCIS. This is particularly true for tumors both large size and high in multicentricity, and for breast conservative surgeryexcised and re-excised specimens that still have DCIS lesions in or near the surgical margins. This will lower the necessity of secondary axillary surgery in case of accidental invasive breast cancer foci and thus decrease morbidity in these patients.
Following breast conserving surgery, several risk factors for DCIS local recurrence are considered to warrant adjuvant radiation. This includes age of the patient, the extent of cancerfree margins after surgical resection, tumor size and grade, the presence of elements of comedo necrosis (15). Four randomized trials, which enrolled patients from 1995 up to September 2006 of adjuvant therapy vs no radiotherapy following local excision for DCIS, provide consistent evidence that radiotherapy (RT) after BCS for DCIS is clinically beneficial. The meta-analysis suggests that radiotherapy reduces the 10-year rate of ipsilateral breast events by approximately $50 \%$ (HR [hazard ratio] 0.47, p<0.001) (16). Interestingly, the results suggest the reduction of ipsilateral events was greater in women older than 50 years than for younger women, but did not differ significantly in cancer free margins, tumor size, effects of comedo necrosis, and high-grade lesions. However, some concerns regarding the inclusion criteria used by these large, randomized trials were raised (15). The investigators recruited women diagnosed only up to 1995, who, during that era, were typically characterized by large DCIS lesions. In addition, lack of stratification by factors such as margin width, close margins $<2 \mathrm{~mm}$ versus $>3 \mathrm{~mm}$, or tumor size (lesions $<20 \mathrm{~mm}$ versus larger tumors), limited the analysis of radiotherapy benefit in the low-risk group (16).

Physicians are still unsure about how the surgical treatment criteria for DCIS should differ from invasive breast cancer with DCIS, especially if patients receive postoperative radiotherapy. This is especially important since mammography-detected DCIS consists of smaller lesions, and subsequently presents a higher probability of negative margins after 
local excision. Postoperative radiation therapy did not lower the DCIS recurrence rate when excised tumors had a tumor-free margins of 10 $\mathrm{mm}$ or more, with a relative risk (RR) of 1.14 (95\% CI, 0.10-12.64) (17). Moreover, in the same study, the authors showed that patients with $1 \mathrm{~mm}$ surgical margins benefited most, with RR of 2.54 (95\% CI, 1.25-5.18), thus lowering the required margin size for adjuvant radiation (17). A more recent analysis showed that patients whose excised tumors had a surgical margin of $2 \mathrm{~mm}$ (odds ratio [OR] 0.36 [95\% CI, 0.27- 0.47]) benefited as much as patients whose excised tumors had larger margins when treated with radiation, shifting the worldwide adjuvant radiation margin size requirement from $1 \mathrm{~mm}$ to $2 \mathrm{~mm}$ (18). Moreover, no significant difference in the rate of local recurrence was seen in patients with tumor-free surgical margins between 2 $\mathrm{mm}$ and $5 \mathrm{~mm}$ or more (OR 1.51 [95\% CI, 0.515.0]). In light of these findings, a secondary resection is recommended when the excised tumor sample has close margins of $<2 \mathrm{~mm}$, which occurs in a minority of patients undergoing BCS or mastectomy (19).

More attention is now paid to individualized DCIS treatment, revealing the need to identify patients with DCIS who are low risk for ipsilateral breast events even without radiotherapy so that overtreatment of these patients can be avoided. This was addressed by a prospective trial including patients with either low- or intermediate-grade DCIS measuring $2.5 \mathrm{~cm}$ or smaller, or high-grade DCIS measuring $1 \mathrm{~cm}$ or smaller, with microscopic margin widths of $3 \mathrm{~mm}$ or wider and no calcifications (20). Assessment of the rate of ipsilateral breast events 5 years after excision without radiation suggests a low local relapse rate in low- to intermediate-grade DCIS with margins of $3 \mathrm{~mm}$ or wider. In contrast, highgrade lesions showed a much higher risk for relapse, at $15.3 \%$ ( $95 \% \mathrm{CI}, 8.2 \%$ to $22.5 \%)$ compared to $6.1 \%$ in lower grade lesions $(95 \%$ CI, $4.1 \%$ to $8.2 \%)(20)$.

While adjuvant radiation after breast conservation is a well-established concept, adjuvant endocrine therapy is not routinely a standard due to controversial data regarding reduction of local recurrences and its complex side effect profile. The NSABP B-24 retrospective study evaluated the effect of tamoxifen vs placebo 5 years after patients underwent lumpectomy and local radiation. Adjuvant tamoxifen was shown to significantly reduce invasive cancer in patients with ER-positive DCIS (HR 0.53, $\mathrm{p}<0.005$ ) but did not reduce tumor recurrence (HR 0.66, p<0.12) (21). In contrast, the only major randomized trial investigating the benefit of adjuvant endocrine therapy, failed to confirm the benefit of tamoxifen in a similar population (22). In this trial, which investigated the effect of tamoxifen and radiotherapy on invasive ipsilateral recurrence, approximately 1700 women were randomly assigned to the following treatment groups: combined radiotherapy and tamoxifen, radiotherapy alone, tamoxifen alone, or no adjuvant therapy. Radiation reduced all new breast events (HR $0.41, \mathrm{p}<0.001)$ and recurrent ipsilateral DCIS (HR 0.68, $\mathrm{p}=0.04$ ), but did not reduce the incidence of ipsilateral invasive disease after tamoxifen (HR 1.41, p=0.8). Tamoxifen treatment was most beneficial when used without radiation, reducing recurrent ipsilateral DCIS (HR 0.71, $\mathrm{p}=0.04$ ) and ipsilateral invasive disease (HR 0.89, $\mathrm{p}<0.6$ ).

Two additional recent randomized phase 3 clinical trials compared endocrine therapy consisting of anastrozole instead of tamoxifen for the treatment of DCIS in postmenopausal women $(23,24)$. In the IBIS-II DCIS trial, radiotherapy "was permitted according to local practice" and was given to $71 \%$ of women in each arm, in contrast to the NSABP B-35 trial, in which all women underwent DCIS resection with free surgical margins and whole-breast radiotherapy. All participants in both studies were required to have estrogen receptor- or progesterone receptor-positive disease. The rate of 10-year breast cancer-free survival was $93.1 \%$ for anastrozole and $89.1 \%$ for tamoxifen $(\mathrm{HR}=0.73 ; \mathrm{p}=0.0234)$. However, the advantage was restricted to women younger than age 60 (HR 0.50 [95\% CI=0.35$0.80]$ ). In contrast, the cancer-free survival 
rate was essentially equal in the IBIS-II DCIS trial (HR 0.89 [95\% CI=0.64-1.32]), and agestratified analyses were not reported. These results reinforce the options that patients have for the treatment of this disease. For example, a patient with severe osteoporosis may prefer to receive tamoxifen since anastrozole is associated with an increased rate of fractures (25). Conversely, patients who are concerned about the risk of blood clots or uterine cancer may prefer anastrozole compared to tamoxifen, the former of which demonstrated lower rates of endometrial and ovarian cancers (26). It needs to be emphasized that all trials investigating endocrine therapy after DCIS only included patients after breast conserving surgery (with or without radiotherapy) but not patients after mastectomy and that the majority of data is available for postmenopausal women.

\section{Future Directions}

Molecular profiling is a newer approach to define risk for DCIS and combining this with clinical and pathologic features may become a widely accepted method to define and stratify the risk of recurrence after lumpectomy (27). Oncotype DX Breast DCIS Score is the only clinically validated and commercially available multigene prognostic signature score, and consists of 12 gene, including proliferation genes, progesterone receptor, a member of the glutathione S-transferase superfamily, and multifunctional enzymes (Table 2) (28). Classification of tissue specimens into three groups based on these genes predicts the 10-year risk of any ipsilateral breast event after BCS. Using this, studies have evaluated the possibility of de-escalating therapy, using surgery alone, without radiation or other adjuvant therapy.

Two Oncotype DCIS score cohorts, namely the ECOG-ACRIN E5194 and Ontario, were included in a combined analysis to validate this method (29). The first study included low- or intermediate-grade DCIS (tumor size $<25 \mathrm{~mm}$ ) and the second study consisted of high-grade DCIS (tumor size $<10 \mathrm{~mm}$ ) (30).
Treatment included surgical excision with a minimum negative margin of $3 \mathrm{~mm}$, or no tumor present upon re-excision. Similarly, only patients who underwent BCS with negative margins with no adjuvant radiotherapy were included in the Ontario study (28). The combination of Oncotype DCIS Score, tumor size, and age at diagnosis identified $25.9 \%$ of patients with an estimated $<8 \%$ 10-year risk of local recurrence, compared to the $17.7 \%$ of cases based on the Oncotype DCIS Score alone. Moreover, no patients with local recurrence (LR) were identified using tumor size and age. The combination also predicted a higher percentage of women with a high risk of LR (21.1\%) (defined as 10-year LR risk $>15 \%$ ) compared to the $18.4 \%$ found by the Oncotype DCIS Score alone or 10.9\% using tumor size and age alone.

A recent study, ECOG-ARIN E5194, evaluated the cost-effectiveness of the Oncotype DCIS Assay (31). The investigators studied the predictive value of (1) no testing, no RT; (2) no testing, RT only for cohort 2; (3) no RT for low-grade DCIS, test for intermediate- and high-grade DCIS, RT for intermediate- or high-risk scores; (4) test all, RT for intermediate-

Table 2. Genes included in the DCIS score

\begin{tabular}{l} 
Oncotype DX Breast DCIS Score \\
Ki-67 \\
AURKA/STK15 \\
BIRC5/survivin \\
CCNB1 \\
MYBL2 \\
PGR \\
GSTM1 \\
ACTB \\
GADPH \\
RPLPO \\
GUS \\
TFRC \\
\hline Note: Gene symbols and full gene name as approved by the HUG0 \\
Gene Nomenclature Committee. \\
Abbreviations: AURKA/STK15: Aurora Kinase A; BIRC5/surviving: \\
Baculoviral IAP Repeat Containing 5; CCNB1: cyclin D; MYBL2: MYB \\
Proto-Oncogene Like 2: Progesterone Receptor, PGR: Glutathione \\
S-transferase Mu 1, GSTM1: Actin Beta, ACTB: Glyceraldehyde-3- \\
phosphate dehydrogenase, GADPH: Large Ribosomal Protein, \\
RPLPO: $\beta$-glucuronidase, GUS; Transferrin Receptor, TFRC
\end{tabular}


or high-risk scores; and (5) no testing, RT for all. The study concluded that use of the DCIS Score lowered the proportion of women undergoing RT per ipsilateral breast event prevented. This data suggests that DCIS score should be used to guide the use of radiation in patients with DCIS who have undergone tumor excision and who were unsure about whether or not to accept radiation. However, no strategy incorporating the DCIS Score was cost effective.

\section{Conclusion}

In summary, the Oncotype assay predicts an individual's risk of local recurrence in combination with other clinical pathological features, including age, tumor size, margin status, and multifocality. In light of current data, this assay might guide the decisionmaking process by eliminating the need for postoperative radiation or endocrine therapy (6).

\section{Conflict of Interest}

$\mathrm{NH}$ reports research grants from Eli Lilly and Company to her institution; personal fees and other for lectures and consulting from Amgen, AstraZeneca, Daiichi-Sankyo, Eli Lilly and Company, Merck Sharp \& Dohme, Novartis, Pfizer, Pierre-Fabre, Roche/Genentech, Sandoz and SeaGen outside to submitted work.

\section{Ethics Statement}

The authors are accountable for all aspects of the work in ensuring that questions related to the accuracy of integrity of any part of the work are appropriately investigated and resolved.

\section{References}

1. Hong YK, McMasters KM, Egger ME, Ajkay N. Ductal carcinoma in situ current trends, controversies, and review of literature. Am J Surg. 2018; 216(5):998-1003.

2. Virnig BA, Tuttle TM, Shamliyan T, Kane RL. Ductal carcinoma in situ of the breast: a systematic review of incidence, treatment, and outcomes. J Natl Cancer Inst. 2010;102(3):170-8.

3. van Seijen M, Lips EH, Thompson AM, Nik-Zainal S, Futreal A, Shelley
Hwang $E$, et al. Ductal carcinoma in situ: to treat or not to treat, that is the question. Br J Cancer. 2019;121(4):285-292.

4. Solin LJ. Management of Ductal Carcinoma In Situ (DCIS) of the Breast: Present Approaches and Future Directions. Curr Oncol Rep. 2019;21(4):33.

5. Rakovitch E, Nofech-Mozes S, Hanna W, Sutradhar R, Baehner FL, Miller DP, et al. Multigene Expression Assay and Benefit of Radiotherapy After Breast Conservation in Ductal Carcinoma in Situ. J Natl Cancer Inst. 2017; 109(4):djw256

6. Nofech-Mozes S, Hanna W, Rakovitch E. Molecular Evaluation of Breast Ductal Carcinoma in Situ with Oncotype DX DCIS. Am J Pathol, 2019. 189(5): p. 975-980.

7. Marmot MG, Altman DG, Cameron DA, Dewar JA, Thompson SG, Wilcox M et al. The benefits and harms of breast cancer screening: an independent review. Br J Cancer. 2013;108(11):2205-40.

8. Worni M, Akushevich I, Greenup R, Sarma D, Ryser MD, Myers ER, et al., Trends in Treatment Patterns and Outcomes for Ductal Carcinoma In Situ. J Natl Cancer Inst. 2015;107(12):djv263.

9. Narod SA, Iqbal J, Giannakeas V, Sopik V, Sun P. Breast Cancer Mortality After a Diagnosis of Ductal Carcinoma In Situ. JAMA Oncol. 2015;1(7): $888-96$.

10. Van Zee KJ, Subhedar P, Olcese C, Patil S, Morrow M. Relationship Between Margin Width and Recurrence of Ductal Carcinoma In Situ: Analysis of 2996 Women Treated With Breast-conserving Surgery for 30 Years. Ann Surg. 2015;262(4):623-31.

11. Arbeitsgemeinschaft, Gynaekologische, and Onkologie, DCIS Guideliness 2021.

12. Shapiro-Wright, H.M. and T.B. Julian, Sentinel lymph node biopsy and management of the axilla in ductal carcinoma in situ. J Natl Cancer Inst Monogr, 2010. 2010(41): p. 145-9.

13. Diaz Casas SE, Serrano Muñoz WA, Buelvas Gómez NA, Osorio Ruiz AM, Aristizábal JÁ, Guzmán Abisaab LH, et al. When is Sentinel Lymph Node Biopsy Useful in Ductal Carcinoma In Situ? The Experience at a Latin American Cancer Center. doi: 10.7759/cureus.16134. eCollection 2021 Jul.

14. Tunon-de-Lara C, Chauvet MP, Baranzelli MC, Baron M, Piquenot J, LeBouédec G, et al. The Role of Sentinel Lymph Node Biopsy and Factors Associated with Invasion in Extensive DCIS of the Breast Treated by Mastectomy: The Cinnamome Prospective Multicenter Study. Ann Surg Oncol. 2015;22(12):3853-60.

15. Group E.B.C.C., EORTC Radiotherapy Group, Bijker N, Meijnen P, Peterse $\mathrm{JL}$, Bogaerts $\mathrm{J}$, et al. Breast-conserving treatment with or without radiotherapy in ductal carcinoma-in-situ: ten-year results of European Organisation for Research and Treatment of Cancer randomized phase III trial 10853--a study by the EORTC Breast Cancer Cooperative Group and EORTC Radiotherapy Group. J Clin Oncol. 2006:24(21):3381-7.

16. Early Breast Cancer Trialists' Collaborative Group (EBCTCG), Correa C, McGale P, Taylor C, Wang Y, Clarke M, et al. Overview of the randomized trials of radiotherapy in ductal carcinoma in situ of the breast. J Natl Cancer Inst Monogr. 2010;2010(41):162-77.

17. Silverstein MJ, Lagios MD, Groshen S, Waisman JR, Lewinsky BS, Martino $S$, Gamagami $P$, et al. The influence of margin width on local control of ductal carcinoma in situ of the breast. N Engl J Med. 1999;340(19):1455-61.

18. Dunne C, Burke JP, Morrow M, Kell MR. Effect of margin status on local recurrence after breast conservation and radiation therapy for ductal carcinoma in situ. J Clin Oncol. 2009;27(10):1615-20.

19. Fitzsullivan E, Lari SA, Smith B, Caudle AS, Krishnamurthy S, Lucci A, et al. Incidence and consequence of close margins in patients with ductal carcinoma-in situ treated with mastectomy: is further therapy warranted? Ann Surg Oncol. 2013;20(13):4103-12.

20. Hughes LL, Wang M, Page DL, Gray R, Solin LJ, Davidson NE, et al. Local excision alone without irradiation for ductal carcinoma in situ of the breast: a trial of the Eastern Cooperative Oncology Group. J Clin Oncol. 2009; 27(32):5319-24.

21. Allred DC, Anderson SJ, Paik S, Wickerham DL, Nagtegaal ID, Swain SM, et al. Adjuvant tamoxifen reduces subsequent breast cancer in women with estrogen receptor-positive ductal carcinoma in situ: a study based on NSABP protocol B-24. J Clin Oncol. 2012;30(12):1268-73. 
22. Cuzick J, Sestak I, Pinder SE, Ellis I0, Forsyth S, Bundred NJ, et al. Effect of tamoxifen and radiotherapy in women with locally excised ductal carcinoma in situ: long-term results from the UK/ANZ DCIS trial. Lancet Oncol. 2011;12(1):21-9. Epub 2010 Dec 7.

23. Margolese RG, Cecchini RS, Julian TB, Ganz PA, Costantino JP, Vallow LA et al. Anastrozole versus tamoxifen in postmenopausal women with ducta carcinoma in situ undergoing lumpectomy plus radiotherapy (NSABP B-35): a randomised, double-blind, phase 3 clinical trial. Lancet. 2016; 387(10021):849-56. Epub 2015 Dec 11.

24. Forbes JF, Sestak I, Howell A, Bonanni B, Bundred N, Levy C, et al Anastrozole versus tamoxifen for the prevention of locoregional and contralateral breast cancer in postmenopausal women with locally excised ductal carcinoma in situ (IBIS-II DCIS): a double-blind, randomised controlled trial. Lancet. 2016:387(10021):866-73. Epub 2015 Dec 11.

25. Eastell R, Adams JE, Coleman RE, Howell A, Hannon RA, Cuzick J, et al., Effect of anastrozole on bone mineral density: 5-year results from the anastrozole, tamoxifen, alone or in combination trial 18233230. J Clin Oncol. 2008;26(7):1051-7.

26. Bergman L, Beelen ML, Gallee MP, Hollema H, Benraadt J, van Leeuwen FE. Risk and prognosis of endometrial cancer after tamoxifen for breast cancer. Comprehensive Cancer Centres' ALERT Group. Assessment of Liver and
Endometrial cancer Risk following Tamoxifen. Lancet. 2000;356(9233): 881-7.

27. Solin LJ, Gray R, Baehner FL, Butler SM, Hughes LL, Yoshizawa C, et al. A multigene expression assay to predict local recurrence risk for ductal carcinoma in situ of the breast. J Natl Cancer Inst. 2013;105(10):701-10.

28. Rakovitch E, Nofech-Mozes S, Hanna W, Baehner FL, Saskin R, Butler SM, et al., A population-based validation study of the DCIS Score predicting recurrence risk in individuals treated by breast-conserving surgery alone. Breast Cancer Res Treat. 2015;152(2):389-98.

29. Rakovitch E, Gray R, Baehner FL, Sutradhar R, Crager M, Gu S, et al. Refined estimates of local recurrence risks by DCIS score adjusting for clinicopathological features: a combined analysis of ECOG-ACRIN E5194 and Ontario DCIS cohort studies. Breast Cancer Res Treat. 2018;169(2): 359-369.

30. Solin LJ, Gray R, Hughes LL, Wood WC, Lowen MA, Badve SS, et al. Surgical Excision Without Radiation for Ductal Carcinoma in Situ of the Breast: 12-Year Results From the ECOG-ACRIN E5194 Study. J Clin Oncol. 2015;33(33):3938-44

31. Raldow AC, Sher D, Chen AB, Recht A, Punglia RS. Cost Effectiveness of the Oncotype DX DCIS Score for Guiding Treatment of Patients With Ductal Carcinoma In Situ. J Clin Oncol. 2016;34(33):3963-3968. 